\title{
Influence of Hastelloy's Cathodic Cage Plasma Deposition on Corrosion Resistance of AISI 304 Stainless Steel and of AISI D6 Tool Steel
}

\author{
Pablo Matheus Oliveira Costa ${ }^{a}$, Petteson Linniker Carvalho Serra ${ }^{b^{*}}$ (D), Renan Matos Monção $o^{b}$, \\ Alan Silva de Menezes ${ }^{c}$, Ferdinando Marco Rodrigues Borges ${ }^{d}$ (D), Thercio Henrique de Carvalho Costa ${ }^{\text {, }}$ \\ Rômulo Ribeiro Magalhães de Sousa $a^{b}$ \\ ${ }^{a}$ Universidade Federal do Piauí, Departamento de Mecânica, Teresina, PI, Brasil \\ ${ }^{b}$ Universidade Federal do Piauí, Programa de Pós-Graduação em Ciência e Engenharia de Materiais, \\ Teresina, PI, Brasil \\ ${ }^{c}$ Universidade Federal do Maranhão, Departamento de Física, São Luís, MA, Brasil \\ 'Instituto Federal do Maranhão, Departamento de Mecânica e Materiais, São Luís, MA, Brasil \\ ${ }^{e}$ Universidade Federal do Rio Grande do Norte, Departamento de Mecânica, Natal, RN, Brasil
}

Received: June 21, 2020; Revised: October 09, 2020; Accepted: November 21, 2020

\begin{abstract}
AISI D6 tool steel and AISI 304 stainless steel are among the most widely used material in the industry. However, this application field can still be expanded through the coatings deposition. In this regard, the objective of this work was to evaluate the impact of coatings application by cathodic cage technique using Hastelloy's cathodic cage, on corrosion resistance of these steels. Two treatment temperatures were compared. The samples were characterized by Optical Microscopy, Scanning Electron Microscopy, Energy Dispersive Spectroscopy, X-Ray Diffraction with the application of the Rietveld routine and corrosion test. The results showed the formation of multiphase layers that contributed to corrosion potentials reduction for treatments at $400{ }^{\circ} \mathrm{C}$, being more effective when applied on AISI D6. It was observed that the corrosion resistance is influenced by the temperature, which was attributed to the precipitation of chromium nitride and iron oxide at $450{ }^{\circ} \mathrm{C}$.
\end{abstract}

Keywords: Cathodic cage, Hastelloy, corrosion resistance, AISI D6, AISI 304.

\section{Introduction}

AISI D6 steel is a cold work tool steel, characterize by high chromium and carbon content and high wear resistance. Its applications include dies for stamping, punches, mandrels and dies for wire drawing ${ }^{1}$. AISI 304 steel is of austenitic stainless steel group, characterized by high corrosion resistance which ensures its application in several industrial areas, with emphasis on food, biomedical, petrochemical and nuclear ${ }^{2-5}$. However, its poor tribological and mechanical properties and a significant tendency to adhesive wear limit its field of application ${ }^{6,7}$.

The implementing of Physical Vapor Deposition (PVD) and Chemical Vapor Deposition (CVD) techniques is adopted for deposition of coatings in structural parts and tools exposed to aggressive environments, contributing to expand its field of application. These coatings are composed mainly of $\mathrm{Al}$, $\mathrm{Ti}, \mathrm{Cr}$ and $\mathrm{N}$ and can contribute significantly to the increase in resistance to abrasive and adhesive wear mechanisms. Additionally, many of these coatings are used to increase corrosion resistance ${ }^{8-10}$.

Among the processing techniques for coatings deposition we can highlight the cathodic cage plasma deposition, consisting in the combination of the following mechanisms: sputtering, which occurs in the cathodic cage and allows the

*e-mail: pettesonlinnikercs@ufpi.edu.br deposition of several coatings depending on the material of the cage; physical adsorption, from the combination with plasma specimens, presenting as an advantage the possibility of using the technique for both oxide and nitride deposition; deposition; desorption and diffusion ${ }^{11-13}$. This technique is widely disseminated in the literature for samples and cathodic cages of various materials ${ }^{11,14-19}$, however, there are no reports of the use of Hastelloy's cage, a nickel alloy characterized by high molybdenum and chromium contents, which together with nickel are responsible for their high pitting corrosion resistance ${ }^{20}$, thus, it is considered that the use of Hastelloy as a cathodic target can contribute to the synthesis of a coating with high corrosion resistance.

In this work, the technique of cathodic cage plasma deposition was applied, using Hastelloy cage, for coatings deposition on AISI D6 tool steel and AISI 304 austenitic stainless-steel aiming verify the influence of treatment on corrosion resistance.

\section{Materials and Methods}

The materials used in this study were AISI D6 cold work tool steel and AISI 304 stainless steel. The first was provided by Villares Metals with the following composition (wt.\%): $2.10 \% \mathrm{C}, 11.50 \% \mathrm{Cr}, 0.70 \% \mathrm{~W}, 0.15 \% \mathrm{~V}$ and $85.55 \mathrm{Fe}$. The AISI 304 stainless steel was provided by Villares Metals 
with the following composition (wt.\%): 0.08\% C, $19.00 \mathrm{Cr}$, $10.00 \% \mathrm{Ni}$ and $70.92 \mathrm{Fe}^{21,22}$. The samples have dimensions of $35 \times 20 \times 6 \mathrm{~mm}^{3}$ polished by silicon carbide papers and mirror finished with diamond paste.

The experimental configuration used in plasma deposition is represented schematically in Figure 1. The samples are positioned inside the cathodic cage and on an alumina disk that keeps them in floating potential. The cathodic cage used was made with Hastelloy C-276 alloy, with has the following composition (wt.\%): $47.30 \% \mathrm{Ni}, 22.00 \% \mathrm{Cr}, 9.00 \% \mathrm{Mo}$, $1.50 \% \mathrm{Co}, 18.50 \% \mathrm{Fe}, 0.50 \% \mathrm{Mn}, 0.60 \% \mathrm{~W}$ and $0.10 \%$ C. Its dimensions are $50 \mathrm{~mm}$ (height) x $90 \mathrm{~mm}$ (diameter), with holes of $8 \mathrm{~mm}$ (diameter) uniformly distributed with distance between centers of $9 \mathrm{~mm}$.

Before all treatments, a pre-sputtering was carried at $350{ }^{\circ} \mathrm{C}$ for $1 \mathrm{~h}$, with mixture $\left(\mathrm{H}_{2}: \mathrm{Ar}=50 \%: 50 \%\right)$ at $1.5 \mathrm{mbar}$ pressure, to remove oxides and contaminants from the cage surface. In the AISI 304 samples the deposition was carried out for $4 \mathrm{~h}$ at two temperatures, $400{ }^{\circ} \mathrm{C}$ and $450{ }^{\circ} \mathrm{C}$, with mixture $\left(\mathrm{H}_{2}: \mathrm{N}_{2}=25 \%: 75 \%\right)$ at 1.0 mbar pressure. The treatment at $400{ }^{\circ} \mathrm{C}$ was repeated in the AISI D6 tool steel sample. A different material was used for the A3 sample to verify the influence of the substrate material on deposition. Table 1 summarizes the parameters used in the treatments.

The thickness of deposited layers was evaluated using a Bel Photonics Optical Microscope (MTM-1A model). The elemental analyses were carried by Energy Dispersive Spectroscopy (EDS) using a Fei Company Scanning Electron Microscope (SEM) (QUANTA FEG 250 model), with acceleration of $20 \mathrm{kV}$. In each sample, measurements were performed at 5 different points. X-ray diffraction (XRD) was carried with the aid of a Shimadzu Diffractometer (LabxXRD 600 model) with $\mathrm{Cu}-\mathrm{K} \alpha$ radiation $(\lambda=1,5406 \mathrm{~A})$ in the $2 \theta$ range from $10^{\circ}$ to $105^{\circ}$ with a scanning velocity of
$2 \%$ min. Rietveld analysis ${ }^{23}$ was performed using the ReX Powder Diffraction Software (0.9.1 version). The corrosion resistance of steels was obtained through the potentiodynamic polarization technique. All electrochemical tests were performed using a three-electrode cell, with a graphite electrode as a counter-electrode, a silver / silver chloride electrode in saturated potassium chloride solution ( $\mathrm{Ag} / \mathrm{AgCl} / \mathrm{KCl}$ sat) as the reference electrode and the samples with and without nitriding, as working eletrode, delimited by an oring of $1 \mathrm{~cm}^{2}$ in area. The samples remained in open circuit for 01 hour to stabilize the system. The electrolyte was a $3.5 \% \mathrm{NaCl}$ solution. The tests were performed on an Autolab Potentiostat (PGSTAT302N model). The polarization test was performed with an initial scanning potential of $0.15 \mathrm{~V}$ below the open circuit potential (ocp - open circuit potential) of each sample and with a final potential of $1.2 \mathrm{~V}$; the scanning speed was $1 \mathrm{mV} / \mathrm{s}$. The potential and corrosion current density were obtained using the Tafel extrapolation method.

\section{Results and Discussion}

\subsection{Optical Microscopy Analysis}

The Figure 2 shows the micrographs obtained for the cross sections of A1, A2 and A3 samples. It can be observed that all treatments resulted in the formation of a surface layer. Figures $2 \mathrm{a}$ and $2 \mathrm{~b}$ refer to treatments applied on the AISI 304 stainless steel substrate at temperatures of $400{ }^{\circ} \mathrm{C}$ and $450{ }^{\circ} \mathrm{C}$, respectively, the layer thickness increases from $7.33 \mu \mathrm{m}$ to $13.16 \mu \mathrm{m}$ as consequence of the increase in treatment temperature, this increase agrees with the works of Panjan ${ }^{24}$, Sousa et al. ${ }^{15}$ and Li et al. ${ }^{25}$. Figure $2 \mathrm{c}$ refer to layer formed on the AISI D6 tool steel substrate, A3 sample. The layer thickness, $7.00 \mu \mathrm{m}$, is similar to that obtained on

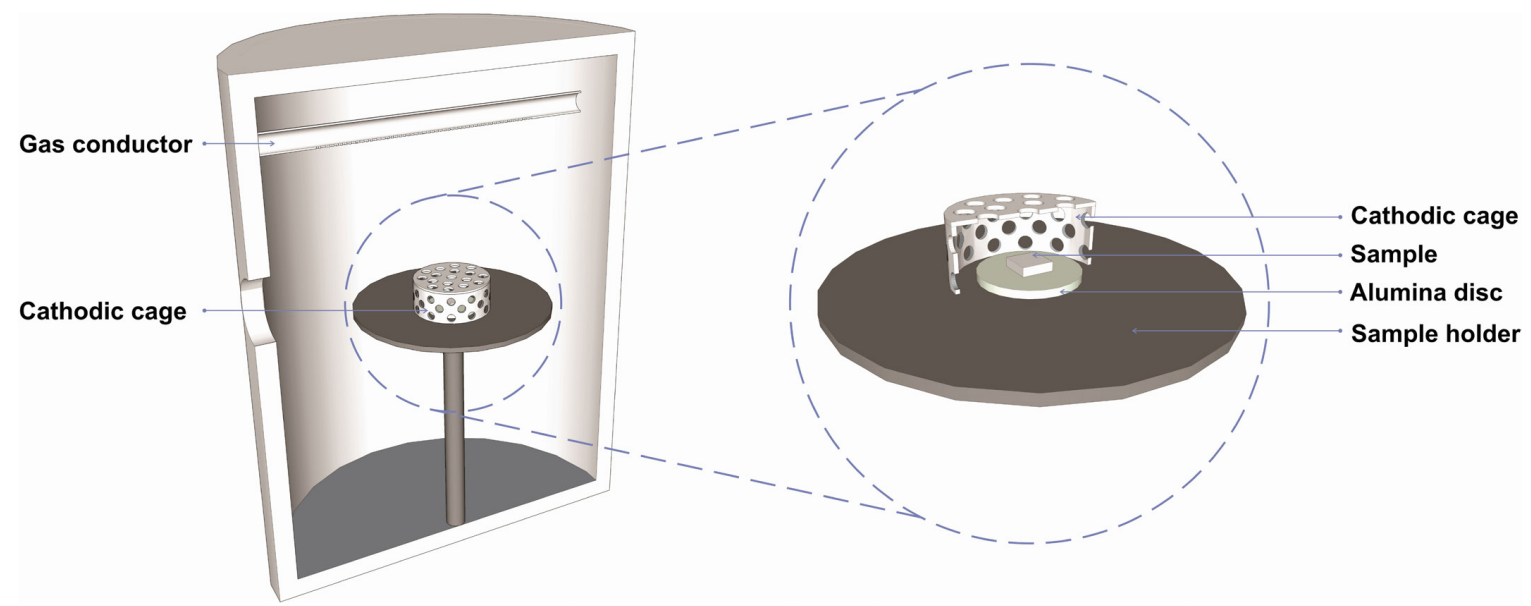

Figure 1. Schematic representation of the cathodic cage plasma deposition process.

Table 1. Parameters used in treatment of cathodic cage plasma deposition.

\begin{tabular}{ccccc}
\hline \multirow{2}{*}{ Samples Labeling } & \multirow{2}{*}{ Substrate Material } & \multicolumn{2}{c}{ Processing Conditions } \\
\cline { 3 - 5 } & Temperature $\left({ }^{\circ} \mathrm{C}\right)$ & Time $(\mathrm{h})$ & Processing Environment (Gasses) \\
\hline A1 & AISI 304 Stainless Steel & 400 & 4 & $\mathrm{H}_{2}: \mathrm{N}_{2}=25 \%: 75 \%$ \\
\hline A3 & AISI 304 Stainless Steel & 450 & 4 & $\mathrm{H}_{2}: \mathrm{N}_{2}=25 \%: 75 \%$ \\
\hline
\end{tabular}



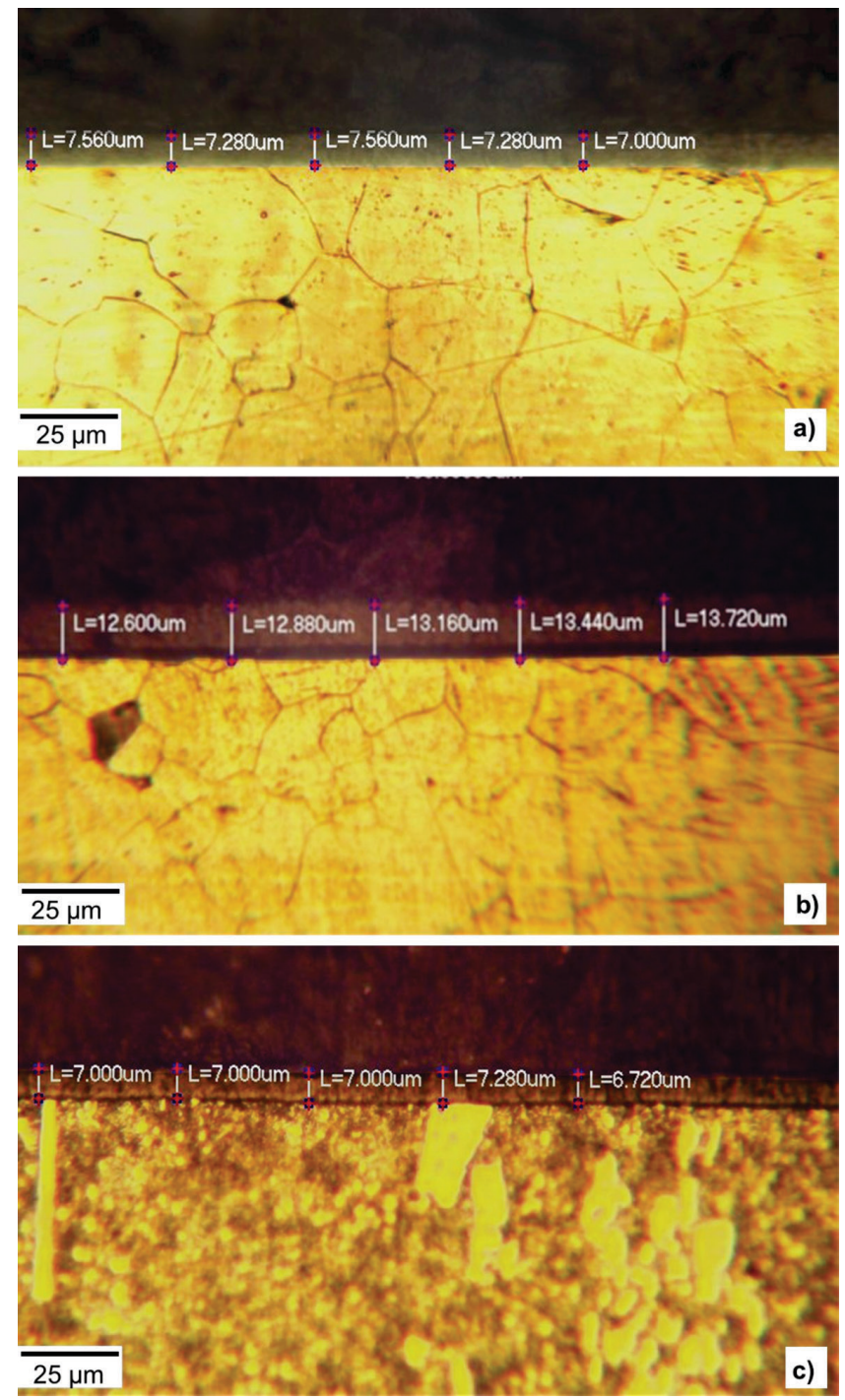

Figure 2. Optical microscopy of the cross sections of treated samples: (a) A1; (b) A2; (c) A3.

AISI 304 stainless steel under the same treatments conditions, A1 sample, which agrees with the layer growth models for samples treated with floating potential presented in previous studies $^{12,26}$ and indicate the sputtering of the cage or of the active screen as the main mechanism for layer growth.

\subsection{Scanning Electron Microscopy and Energy Dispersive Spectroscopy Analyses}

The SEM images of the surfaces of A1, A2 and A3 samples are shown in Figure 3. The morphology analysis of these samples reveals a typical characteristic of coatings deposited by PVD processes, the presence of pores $^{27-30}$. A more uniform layer was obtained in the treatment at $450{ }^{\circ} \mathrm{C}$, Figure $3 \mathrm{~b}$, which is evidenced by the absence of void observed in the coatings deposited at $400{ }^{\circ} \mathrm{C}$ and indicated by arrows in Figure 3. The result does not show any influence of the substrate material for the presence of these defects, because they went observed both in the coating deposited on AISI 304 stainless steel, and on the deposited on AISI D6 tool steel, Figures $3 \mathrm{a}$ and $3 \mathrm{c}$, respectively.
The defects in PVD coatings originate from irregularities on the surface, considering the application of the same metallographic preparation conditions for the three samples and the occurrence of the same defects in different substrates, the irregularities on the surface are originated in the deposition process ${ }^{24,25,31}$. The coatings were deposited in a reactor controlled by a direct current source in which the temperature is controlled by the voltage, it was previously proven that in the PVD coatings deposition higher voltages favor a lower density of defects ${ }^{32}$, this behavior may be associated with a higher sputtering rate on the target and the consequently a higher deposition rate on the substrate, which was evidenced by greater layer thickness in the deposition at $450{ }^{\circ} \mathrm{C}$ in the results of optical microscopy, the higher deposition rate improves the conditions to completely cover the surface, reducing the influence of irregularities, and may justify the greater uniformity presented by the coating of the A2 sample. Another important factor for the greater uniformity presented by A2 sample is the greater mobility of atoms, provided by the increase in temperature, which 
favors obtaining denser coatings and the decrease number of voids and pores ${ }^{33}$.

Table 2 presents the results of the quantitative analysis made by EDS. The values presented are the averages of the weight percentages with the respective standard deviations of five distinct points in each sample. In all samples was observed presence of carbon, nitrogen, oxygen, tungsten, molybdenum, chromium, manganese, iron and nickel, was also observed significant amounts of oxygen that can be associated with surface reactions between oxygen and the coating after treatment ${ }^{34}$. These reactions are favored by the high percentage of transition metals, mainly chromium, molybdenum, iron and nickel, which increase the oxygen adsorption rate ${ }^{35,36}$. The $\mathrm{A} 3$ sample showed a higher amount of oxygen, which is associated with a higher density of defects in the coating (greater number of pores and voids) and consequently, greater surface area, in agreeing with the differences presented for the layer morphology in Figure 3. However, it is necessary to explain why the A1 coating presented oxygen content equal to that of $\mathrm{A} 2$ sample, even with a greater number of visible defects. No other significant differences were observed in the chemical composition of the films formed on the substrates of A1 and A3 samples, which reinforces the permanence of the samples in floating potential during treatment, with a sputtering mechanism concentrated in the cage ${ }^{37-39}$.

An important point is the highest nickel percentage presented by the treated samples when compared to the percentages presented for the starting materials. The measured points average was $47.62 \%$ in A1 sample and $48.96 \%$ in A2 sample, which is approximately five times higher than the value provided by the manufacturer, $10 \%$ for AISI 304 stainless steel. Regarding AISI D6 tool steel, the result is even more significant, because the initial composition does

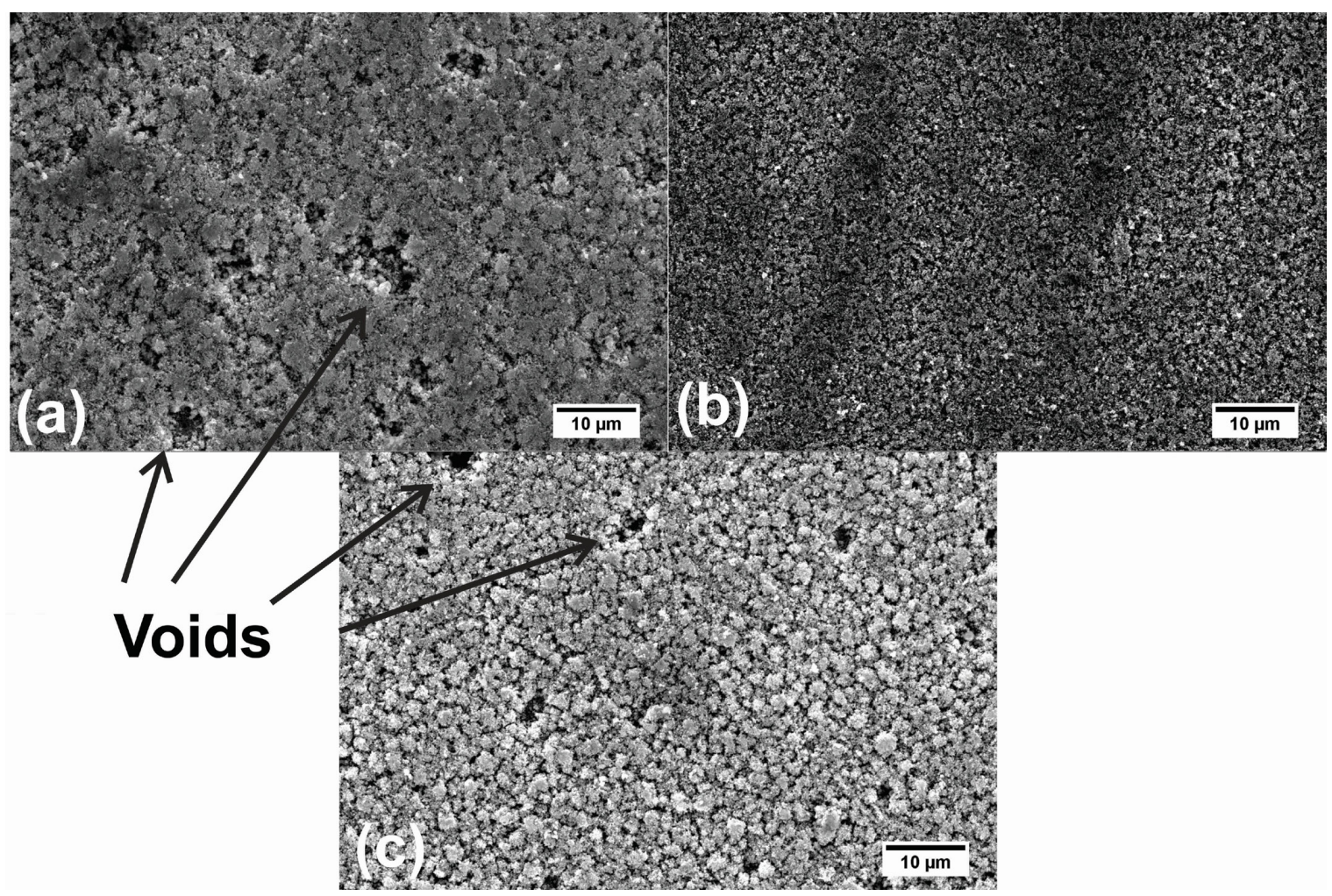

Figure 3. Surface morphology of samples with cathodic cage plasma deposition: A1; A2 and A3.

Table 2. Percentages by weight of the elements found by EDS - Energy Dispersion Spectrosopy in the treated samples.

\begin{tabular}{crrr}
\hline \multirow{2}{*}{ Element } & \multicolumn{1}{c}{ Samples } \\
\cline { 2 - 4 } & $\mathrm{A} 1$ & $\mathrm{~A} 2$ & $\mathrm{~A} 3$ \\
\hline $\mathrm{C}$ & $3.84 \pm 3,46$ & $2.74 \pm 1.60$ & $4.78 \pm 1.18$ \\
\hline $\mathrm{N}$ & $5.6 \pm 0.95$ & $5.32 \pm 3.25$ & $6.4 \pm 1.30$ \\
\hline $\mathrm{O}$ & $5.68 \pm 1.09$ & $5.54 \pm 1.26$ & $8.12 \pm 1.38$ \\
\hline $\mathrm{W}$ & $2.08 \pm 0.04$ & $3.12 \pm 0.38$ & $2.42 \pm 0.43$ \\
\hline $\mathrm{Mo}$ & $7.68 \pm 0.29$ & $10.9 \pm 0.83$ & $8.2 \pm 0.37$ \\
\hline $\mathrm{Cr}$ & $11.2 \pm 0.92$ & $12.76 \pm 1.07$ & $10.4 \pm 0.81$ \\
\hline $\mathrm{Mn}$ & $0.925 \pm 0.05$ & $0.72 \pm 0.41$ & $0.64 \pm 0.38$ \\
\hline $\mathrm{Fe}$ & $15.64 \pm 1.36$ & $9.66 \pm 0.70$ & $10.8 \pm 1.09$ \\
\hline $\mathrm{Ni}$ & $47.62 \pm 2.87$ & $48.96 \pm 3.59$ & $47.60 \pm 2.65$
\end{tabular}


not present nickel among the constituents and A3 sample presented an average of $47.60 \%$ nickel, what evidence the elements transfer from the cathodic cage to the sample during the formation of layers presented in the results of optical microscopy and agreeing with the presence of cathodic sputtering and physical adsorption mechanisms, described by Zhao et al. ${ }^{12}$. Similar results were obtained with application of ASPN with 304 austenitic stainless steel active screen on samples of ferritic stainless steel $430^{40}$. The nitrogen presence in considerable levels is an indicative of the elements interaction removed from the cathodic cage with the reactive gas for nitrides formation.

\subsection{X-Ray Diffraction (XRD) Analysis}

Figure 4 shows the X-Ray diffraction patterns for A1, A2 and A3 samples and illustrates the phases Bragg peaks identified in the coatings, as well as the profiles calculated by the Rietveld routine $\mathrm{e}^{23,41}$ and their respective differences for the experimental patterns.

XRD patterns of samples submitted to plasma deposition using a Hastelloy cage: (a) A1; (b) A2 and (c) A3.

According to the analysis of XRD patterns illustrated in Figure $4 \mathrm{a}$, the XRD peaks of A1 sample can be associated with a combination of four distinct phases with the following percentage values: $66.886 \%$ expanded austenite, $16.569 \%$ nickel $(\mathrm{Ni}), 8.721 \%$ chromium $(\mathrm{Cr})$ and $7.824 \%$ chromium nitride $(\mathrm{CrN})$, studies involving only conventional nitriding did not show precipitation of chromium nitride at $400{ }^{\circ} \mathrm{C}$, as the lower temperature makes it difficult chromium removal from the substrate for formation of chromium nitride $e^{6,42,43}$, the portion of chromium nitride presented (7.824\%) may be associated with chromium removed from the cathodic cage.

The respective positions of these peaks are in agreement with the results reported in the Inorganic Crystal Structure Database (ICSD), cards $\mathrm{N}^{\circ} 31899^{44}, 76667^{45}, 64711^{46}$ and $53146^{47}$, which were used to model the theoretical profile of XRD with their specific positions. The parameters obtained with refinement: $R_{\mathrm{p}}(\%)=4.141, R_{\exp }(\%)=3.304$, $R_{\mathrm{wp}}(\%)=5.694, \chi^{2}=2.969$ and $G O F=1.723$, prove the agreement $^{23,48}$. The experimental lattice parameters, atomic positions and the positions occupancy calculated by the Rietveld refinement method ${ }^{23,41}$ are presented in Table 3.

Results obtained for the A1 sample after application of structural refinement by the method of Rietveld.

The patterns presented for A2 sample in Figure $4 \mathrm{~b}$ show the presence of five distinct phases with the following percentage values: $47.125 \%$ expanded austenite, $7.765 \%$ nickel (Ni), 1.728\% molybdenum nitride $\left(\mathrm{Mo}_{2} \mathrm{~N}_{0.76}\right), 22.010 \%$ chromium nitride $(\mathrm{CrN})$ and $23.951 \%$ iron oxide $\left(\mathrm{Fe}_{3} \mathrm{O}_{4}\right)$. The expanded austenite phase in A2 sample is richer in nitrogen than that formed in A1 sample, nitrogen occupancy in expanded austenite Table 3 and Table 4, this difference is related to the increase in nitrogen diffusion, provided by temperature elevation, the temperature influence can also justify the increase in the percentage of chromium nitride formed, which occurs as a consequence of the diffusion of chromium from the substrate at higher temperatures ${ }^{6,30}$. The large percentage of iron oxide presented can be associated with this higher precipitation of chromium nitride, which contributes to the increase in the amount of free iron on the

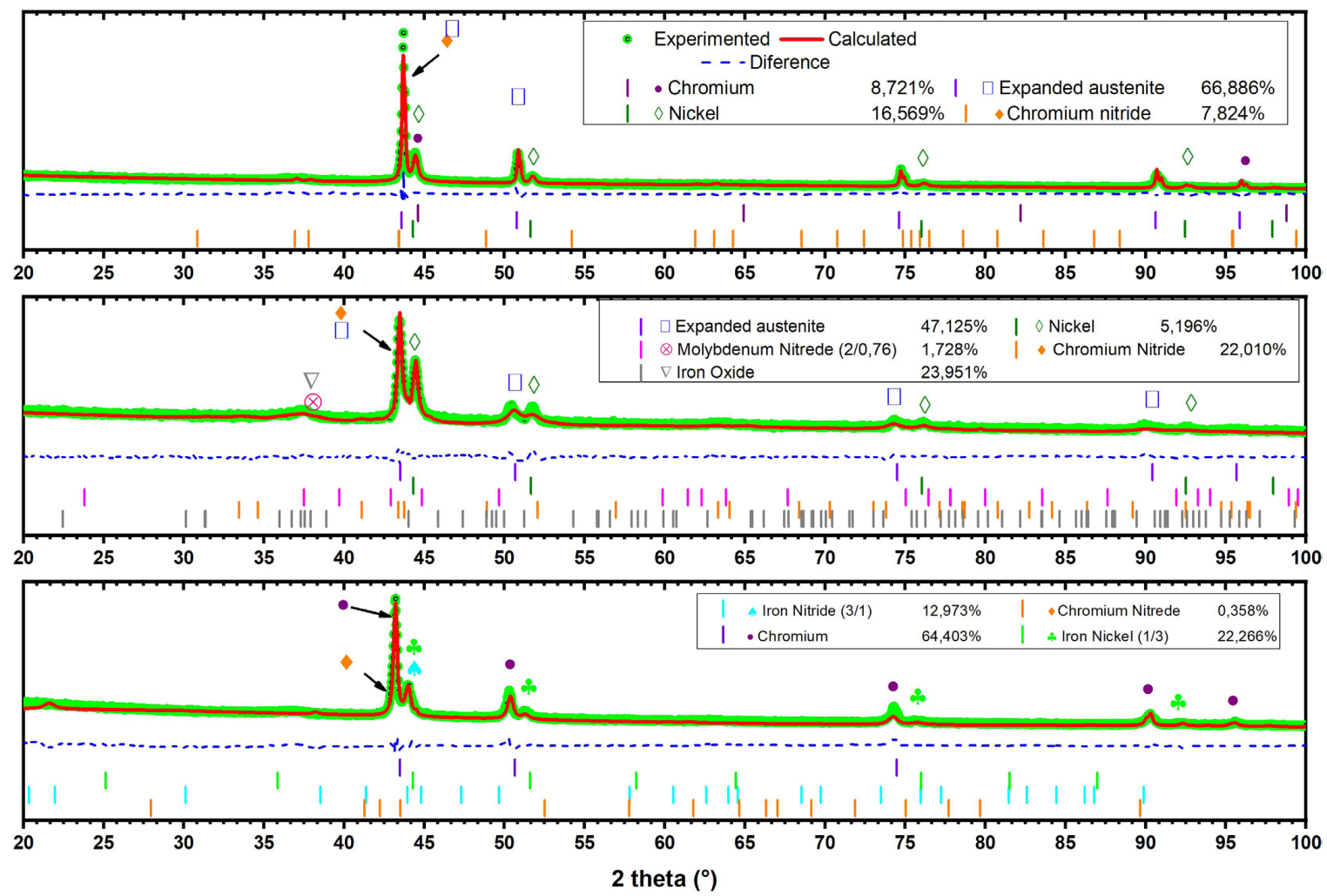

Figure 4. X-Ray diffraction pattern of treated samples: (a) A1; (b) A2 and (c) A3. 
Table 3. Results obtained for the A1 sample after application of structural refinement by the method of Rietveld.

\begin{tabular}{|c|c|c|c|c|c|}
\hline \multicolumn{6}{|c|}{ Chromium (Cr) 8.721\% } \\
\hline \multicolumn{6}{|c|}{ Lattice parameters $(\AA)$} \\
\hline \multicolumn{2}{|c|}{$\mathrm{a}$} & \multicolumn{2}{|c|}{$\mathrm{b}$} & \multicolumn{2}{|c|}{$\mathrm{c}$} \\
\hline \multicolumn{2}{|c|}{2.8698} & \multicolumn{2}{|c|}{2.8698} & \multicolumn{2}{|c|}{2.8698} \\
\hline \multicolumn{2}{|c|}{ ‘ } & \multicolumn{2}{|c|}{ Atomics positions } & & \\
\hline Atoms & $\mathrm{x}$ & $\mathrm{y}$ & $\mathrm{z}$ & Occupancy & $\mathrm{U}_{\text {iso }}$ \\
\hline $\mathrm{Cr}$ & 0 & 0 & 0 & 1 & 0 \\
\hline \multicolumn{6}{|c|}{ Expanded Austenite $66.886 \%$} \\
\hline \multicolumn{6}{|c|}{ Lattice parameters $(\AA)$} \\
\hline \multicolumn{2}{|c|}{$\mathrm{a}$} & \multicolumn{2}{|c|}{$\mathrm{b}$} & \multicolumn{2}{|c|}{$\mathrm{c}$} \\
\hline \multicolumn{2}{|c|}{3.5940} & \multicolumn{2}{|c|}{3.5940} & \multicolumn{2}{|c|}{3.5940} \\
\hline \multicolumn{6}{|c|}{ Atomics positions } \\
\hline Atoms & $\mathrm{x}$ & $\mathrm{y}$ & $\mathrm{z}$ & Occupancy & $\mathrm{U}_{\mathrm{iso}}$ \\
\hline $\mathrm{Fe}$ & 0 & 0 & 0 & 1 & 0 \\
\hline $\mathrm{N}$ & 0.5000 & 0.5000 & 0.5000 & 0.0324 & 0 \\
\hline \multicolumn{6}{|c|}{ Nickel (Ni) $16.569 \%$} \\
\hline \multicolumn{6}{|c|}{ Lattice parameters $(\AA)$} \\
\hline \multicolumn{2}{|c|}{$\mathrm{a}$} & \multicolumn{2}{|c|}{$\mathrm{b}$} & \multicolumn{2}{|c|}{$\mathrm{c}$} \\
\hline \multicolumn{2}{|c|}{3.5382} & \multicolumn{2}{|c|}{3.5382} & \multicolumn{2}{|c|}{3.5382} \\
\hline \multicolumn{6}{|c|}{ Atomics positions } \\
\hline Atoms & $\mathrm{x}$ & $\mathrm{y}$ & $\mathrm{z}$ & Occupancy & $\mathrm{U}_{\mathrm{ise}}$ \\
\hline $\mathrm{Ni}$ & 0 & 0 & 0 & 1 & 0 \\
\hline \multicolumn{6}{|c|}{ Chromium Nitride (CrN) 7.824\% } \\
\hline \multicolumn{6}{|c|}{ Lattice parameters $(\AA)$} \\
\hline \multicolumn{2}{|c|}{$\mathrm{a}$} & & & & \\
\hline & & & & & \\
\hline & & & & & \\
\hline Atoms & $\mathrm{x}$ & $\mathrm{y}$ & $\mathrm{z}$ & Occupancy & $\mathrm{U}_{\mathrm{ise}}$ \\
\hline $\mathrm{Cr}$ & 0 & 0 & 0.2400 & 1 & 0 \\
\hline $\mathrm{N}$ & 0 & 0.5000 & 0.2600 & 1 & 0 \\
\hline
\end{tabular}

surface and consequently to its combination with oxygen in the atmosphere after treatment ${ }^{42}$.

The peaks positions are in accordance with the results published in the Inorganic Crystal Structure Database (ICSD), cards $\mathrm{N}^{\circ} 31901^{44}, 76667^{45}, 654542^{49}, 53146^{47}$ and $31156^{50}$, the XRD theorical profile with its specific positions was modeled from these cards. The parameters obtained with the refinement: $\operatorname{Rp}(\%)=4.560, \operatorname{Rexp}(\%)=3.623$, $\operatorname{Rwp}(\%)=6.568, \chi 2=3.287$ and $\mathrm{GOF}=1.813$, prove the agreement $\mathrm{t}^{23,48}$. The experimental lattices, atomics positions and positions occupancy calculated by Rietveld refinement method $^{23,41}$ are presented in Table 4.

According to Figure $4 \mathrm{c}$ the XRD peaks of A3 sample can be associated with a combination of four distinct phases with the following percentages values: $64.403 \%$ chromium $(\mathrm{Cr})$, $0.358 \%$ chromium nitride $(\mathrm{CrN}), 22.266 \%$ iron-nickel $\left(\mathrm{FeNi}_{3}\right)$ and $12.973 \%$ iron nitride $\left(\mathrm{Fe}_{3} \mathrm{~N}\right)$. As already discussed, the treatments of A1 and A3 samples were performed under the same conditions, the results obtained in the characterization by EDS did not show significant differences in the coatings chemical composition, which was expected, because the sputtering and adsorption mechanisms are not influenced by the substrate, but the XRD results presented different phase formation for the two samples, which can be explained by the presence of the desorption and diffusion mechanisms, which are directly related to the crystalline structure and the chemical composition of the substrate ${ }^{12}$.

The expanded austenite formed in the coating of A1 sample consists of the nitrogen solid solution in the austenite phase of $\gamma$ iron and is facilitated by the greater nitrogen solubility in the face centered cubic (fcc) structure. In the A3 sample, AISI D6 tool steel is ferritic and presents the (bcc) body centered cubic structure, the low solubility of nitrogen in this phase explains the precipitation of iron nitride only in the A3 sample $\mathrm{e}^{21,22,51,52}$. As discussed for A2 sample, chromium nitride precipitation is facilitated at temperatures from $450{ }^{\circ} \mathrm{C}$, which explains the low percentage presented for the sample treated at $400{ }^{\circ} \mathrm{C}^{6,42,53}$. The A3 sample was the only one to present $\mathrm{Fe}_{3} \mathrm{~N}$ phase formation, what can be associated with the differences in diffusion coefficients in the phases, the iron and nickel diffusion coefficients in ferrite are three orders of magnitude greater than in the austenite ${ }^{54}$.

Peaks positions are in agreement with the results published in the Inorganic Crystal Structure Database (ICSD), cards $\mathrm{N}^{\circ} 33576^{55}, 53146^{47}, 632929^{56}$, and Crystallography Open Database, card 1534885. Based on these cards, the XRD theoretical profile with its specific positions was modeled. The parameters obtained with refinement: $R_{\mathrm{p}}(\%)=5.770, R_{\exp }$ $(\%)=2.873, R_{\mathrm{wp}}(\%)=7.608, \chi^{2}=6.416$ and $G O F=2.533$, prove this agreement ${ }^{23,48}$. The experimental lattice parameters, 
Table 4. Results obtained for the A2 sample after application of structural refinement by the method of Rietveld.

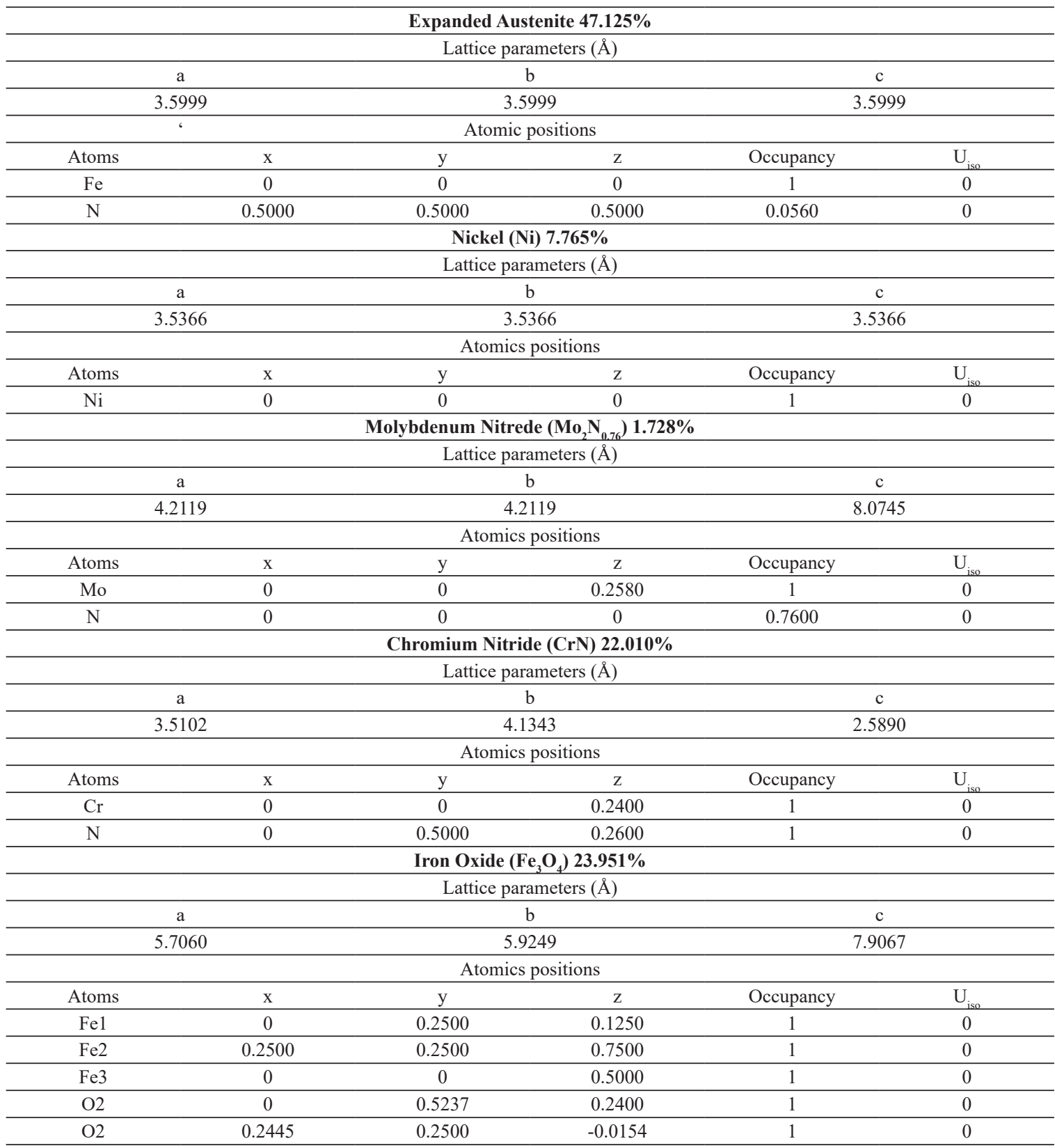

$R_{\mathrm{p}}(\%)=4.560, R_{\exp }(\%)=3.623, R_{\mathrm{wp}}(\%)=6.568, \chi^{2}=3.287$ and $G O F=1.813$

atomic positions, and positions occupancy calculated by the Rietveld refinement method ${ }^{23,41}$ are presented in Table 5.

\subsection{Corrosion Resistance Analysis}

The Figure 5 shows the potentiodynamic polarization curves for the A1, A2 and A3 samples, in addition to those referring to samples without treatment, AISI 304 and AISI D6.

The result of applying the Tafel Extrapolation Method to the experimental curves from Figure 5 is presented in Table 6 and allows a better analysis of the samples behavior.

The positions of the potentiodynamic polarization curves for the AISI 304 stainless steel samples with and without treatment, presented in Figure 5a, reveal an increase in corrosion resistance as an effect of the treatment at $400{ }^{\circ} \mathrm{C}$, A1 sample, and a decrease in corrosion resistance when the treatment is performed at the temperature of $450{ }^{\circ} \mathrm{C}$, A2 sample.

The curves for A1 and AISI 304 samples present a well-defined range showing passivation behavior, indicated by arrows in Figure 5, this behavior was not observed in A2 sample.

The data presented in Table 6 express this effect quantitatively, it is noted that the A1 sample presented corrosion and pite potentials nobler than those of the untreated sample. Although these parameters indicate the increase of corrosion resistance, since the active processes occur in 
higher potentials than for the untreated sample, AISI 304, we can observe that the sample presented a higher corrosion current density, which implies that once the corrosion potential is reached, the process occurs more quickly. The A2 sample did not suffer passivation because it presented a high percentage of $\mathrm{CrN}(22.010 \%)$ as can be observed in the results of x-ray diffraction for the sample. Such precipitation promotes an impoverishment of chromium in the matrix, resulting in a decrease in the resistance to corrosion, also hindering the formation of the characteristic passive layer of these materials ${ }^{57}$. Besides presenting the above mentioned phase, there is a high percentage of iron oxide $(23,951 \%)$

Table 5. Results obtained for the A3 sample after application of structural refinement by the method of Rietveld.

\begin{tabular}{|c|c|c|c|c|c|}
\hline \multicolumn{6}{|c|}{ Iron Nitride $\left(\mathrm{Fe}_{3} \mathrm{~N}\right) \mathbf{1 2 . 9 7 3 \%}$} \\
\hline \multicolumn{6}{|c|}{ Lattice parameters $(\AA)$} \\
\hline \multicolumn{2}{|c|}{$\mathrm{a}$} & \multicolumn{2}{|c|}{$\mathrm{b}$} & \multicolumn{2}{|c|}{$\mathrm{c}$} \\
\hline \multicolumn{2}{|c|}{4.6820} & \multicolumn{2}{|c|}{4.6820} & \multicolumn{2}{|c|}{4.3600} \\
\hline \multicolumn{2}{|c|}{ ‘ } & \multicolumn{2}{|c|}{ Atomics positions } & & \\
\hline Atoms & $\mathrm{x}$ & $\mathrm{y}$ & $\mathrm{z}$ & Occupancy & $\mathrm{U}_{\mathrm{iss}}$ \\
\hline $\mathrm{Fe}$ & 0 & 0 & 0.3333 & 1 & 0 \\
\hline N1 & 0 & 0 & 0 & 1 & 0 \\
\hline N2 & 0.3333 & 0.6667 & 0.5000 & 1 & 0 \\
\hline \multicolumn{6}{|c|}{ Chromium Nitride (CrN) $0.358 \%$} \\
\hline \multicolumn{6}{|c|}{ Lattice parameters $(\AA)$} \\
\hline \multicolumn{2}{|c|}{$\mathrm{a}$} & \multicolumn{2}{|c|}{$\mathrm{b}$} & \multicolumn{2}{|c|}{$\mathrm{c}$} \\
\hline \multicolumn{2}{|c|}{3.0000} & \multicolumn{2}{|c|}{2.8803} & \multicolumn{2}{|c|}{3.1887} \\
\hline \multicolumn{6}{|c|}{ Atomics positions } \\
\hline Atoms & $\mathrm{x}$ & $\mathrm{y}$ & $\mathrm{z}$ & Occupancy & $\mathrm{U}_{\mathrm{ise}}$ \\
\hline $\mathrm{Cr}$ & 0 & 0 & 0.2400 & 1 & 0 \\
\hline $\mathrm{N}$ & 0 & 0.5000 & 0.2600 & 1 & 0 \\
\hline \multicolumn{6}{|c|}{ Iron Nickel $\left(\mathrm{FeNi}_{3}\right) 22.266 \%$} \\
\hline \multicolumn{6}{|c|}{ Lattice parameters $(\AA)$} \\
\hline \multicolumn{2}{|c|}{$\mathrm{a}$} & \multicolumn{2}{|c|}{$\mathrm{b}$} & \multicolumn{2}{|c|}{$\mathrm{c}$} \\
\hline \multicolumn{2}{|c|}{3.5394} & \multicolumn{2}{|c|}{3.5394} & \multicolumn{2}{|c|}{3.5394} \\
\hline \multicolumn{6}{|c|}{ Atomics positions } \\
\hline Atoms & $\mathrm{x}$ & $\mathrm{y}$ & $\mathrm{z}$ & Occupancy & $\mathrm{U}_{\mathrm{ise}}$ \\
\hline $\mathrm{Fe}$ & 0 & 0 & 0 & 1 & 0 \\
\hline $\mathrm{Ni}$ & 0 & 0.5000 & 0.5000 & 1 & 0 \\
\hline \multicolumn{6}{|c|}{ Chromium (Cr) 64.403\% } \\
\hline \multicolumn{6}{|c|}{ Lattice parameters $(\AA)$} \\
\hline & & & & & \\
\hline & & & & & \\
\hline & & & & & \\
\hline Atoms & $\mathrm{x}$ & $\mathrm{y}$ & $\mathrm{z}$ & Occupancy & $\mathrm{U}_{\text {iso }}$ \\
\hline $\mathrm{Cr}$ & 0 & 0 & 0 & 1 & 0 \\
\hline
\end{tabular}

(a)

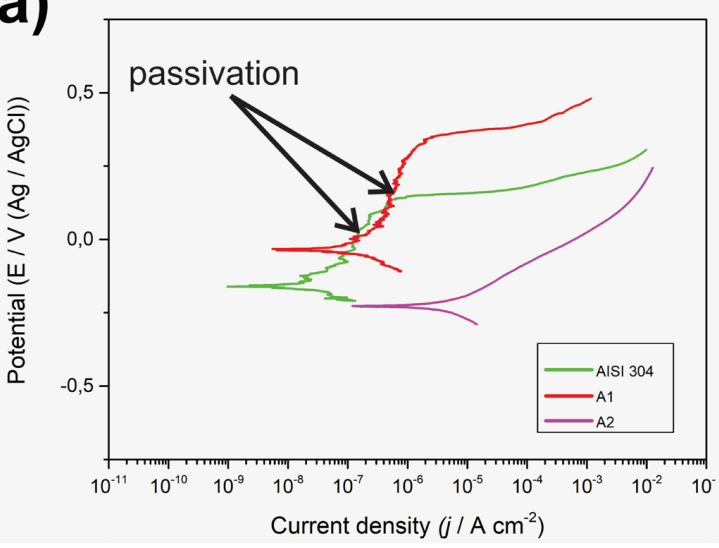

(b)

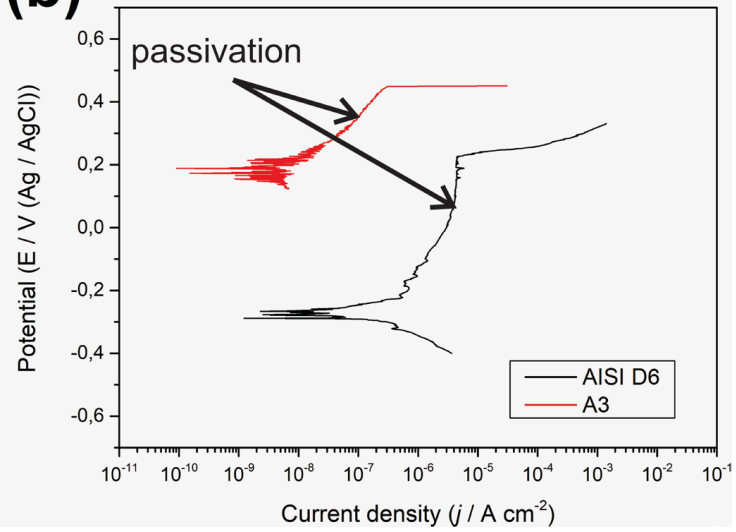

Figure 5. Potentiodynamic polarization curves of treated samples: (a) AISI 304, A1 and A2; (b) AISI D6 and A3. 
Table 6. Values of the corrosion potential $\left(\mathrm{E}_{\text {corrosion }}\right)$, corrosion current density $\left(\mathrm{i}_{\text {corrosion }}\right)$ passivation current density $\left(\mathrm{i}_{\text {passivation }}\right)$ and pitting potential $\left(\mathrm{E}_{\text {pite }}\right)$ of the samples: A1, A2, A3, AISI 304 and AISI D6.

\begin{tabular}{ccccc}
\hline Samples & $\mathbf{E}_{\text {corrosion }}(\mathbf{V})$ & $\mathbf{i}_{\text {corrosion }}(\mathbf{A ~ c m 2})$ & $\mathbf{i}_{\text {passivation }}(\mathbf{A}$ cm-2 $)$ & $\mathbf{E}_{\text {pite }}(\mathbf{V})$ \\
\hline AISI 304 & -0.17 & $1.27 \times 10^{-8}$ & $1.29 \times 10^{-7}$ & 0.13 \\
\hline A1 & -0.03 & $1.31 \times 10^{-7}$ & $6.13 \times 10^{-7}$ & 0.34 \\
\hline A2 & -0.23 & $2.04 \times 10^{-6}$ & - & - \\
\hline AISI D6 & -0.26 & $1.49 \times 10^{-7}$ & $3.30 \times 10^{-6}$ & 0.22 \\
\hline A3 & 0.19 & $4.12 \times 10^{-9}$ & $8.37 \times 10^{-8}$ & 0.45 \\
\hline
\end{tabular}

that presents a lot of porosity, offering interaction channels between the external environmental and the substrate ${ }^{42}$, and consequently low resistance to corrosion. These phases do not induce the passivation of the material, occurring a phenomenon known as anodic dissolution, as can be observed in the anodic part of the curve of the sample A2.

In the region of passivation occurs the manifestation of micropites and their immediate repassivation, because the passivation reactions are still more predominant than the formation of pites. However, when there is an abrupt increase in current density in samples A1 (Epite $=0.34 \mathrm{~V})$, AISI $304($ Epite $=0.13 \mathrm{~V})$, AISI D6 $($ Epite $=0.22 \mathrm{~V})$ and A3 (Epite $=0.45 \mathrm{~V}$ ) the phenomenon known as transpassivation occurs; that is, the mechanical breakdown of the passive film.

The A2 sample, besides not presenting passivation also presented at the lower corrosion potential and at the higher corrosion current density. The better behavior of A1 sample can be associated with the phases formed in the coating. Previous studies ${ }^{6,9,46}$ showed that nitrogen increases the austenite corrosion resistance, as observed in the XRD results, $66 \%$ of the coating consists of expanded austenite. The presence of significant amount of chromium may explain the passivation behavior, considering that chromium is the main responsible for the formation of passive film in stainless steels ${ }^{58,59}$. The presence of chromium nitride usually displaces the potentiodynamic curves to higher corrosion current densities, what can explain the higher current value compared to the untreated sample ${ }^{58,60}$. The increase in the corrosion resistance of A1 sample corroborates in the hypothesis raised that the chromium nitride presented in the diffractograms of A1 sample was formed from the sputtered chromium from the cathodic cage.

The application of deposition in the AISI D6 tool steel substrate showed promising results in increasing corrosion resistance, which can be observed by the relative position of the potentiodynamic curves in Figure 5b. The arrows indicate that curves represented region corresponding to sample passivation behavior. The qualitative results confirm this behavior, as show can be in Table 6 . There was a substantial increase in corrosion and pite potentials, showing a greater resistance to the active corrosion events. The decrease in the corrosion current density indicating a lower corrosion speed for the A3 sample, an effect not observed with the treatment on stainless steel AISI 304. Thus, the treatment presents more satisfactory results on AISI D6 tool steel, the which is also observed directly comparing the results obtained for A1 and A3 samples, that are clearly more nobles values for the last one, even starting from a material less corrosion resistant. The results corroborate with presented in the diffractogram for A3 sample, where chromium it is the main phase formed, in addition to the formation of $\mathrm{Fe}_{3} \mathrm{~N}$ iron nitride and of the $\mathrm{FeNi}_{3}$ phase, that in comparison with $\alpha$ iron, have less chemical affinity with the oxygen ${ }^{4,42}$.

\section{Conclusions}

The results of this work allowed us to conclude that plasma deposition with Hastelloy cathodic cage can be used to effectively increase the corrosion resistance of AISI 304 stainless steel and especially of AISI D6 tool steel. It was verified that all treatments resulted in multiphase films and that the structure of these phases was influenced by the treatment temperature and the substrate material.

It was verified that the treatments at $450{ }^{\circ} \mathrm{C}$, present more uniform films and less visible defects in the morphology, but they contribute to the decrease of corrosion resistance which was associated with the formation of chromium nitride and of iron oxide.

The temperature of $400{ }^{\circ} \mathrm{C}$ was more suitable for the application of the coating, with the samples showing passivation behavior for the two studied substrates. When applied on AISI 304 stainless steel, the film predominantly formed by expanded austenite reduced the corrosion potential. However, the best result was presented on AISI D6 tool steel, the film composed mainly of free chromium and iron-nickel phase proved to be efficient in decreasing the interaction between iron and oxygen and contributed to the reduction of the corrosion rate of the AISI D6 tool steel.

\section{Acknowledgements}

The authors thank the Graduate Program in Materials Science and Engineering (CT-UFPI), Plasma Laboratory LabPlasma/UFPI.

\section{References}

1. Souza RR, Brandim AS, Oliveira MD, Alves C Jr. Aço ferramenta para trabalho a frio Aisi D6 tratado termicamente e nitretato em plasma. Rev Bras Apl Vácuo. 2008;27:223-7.

2. Rahman M, Haider J, Hashmi MSJ. Low temperature plasma nitriding of 316 stainless steel by a saddle field fast atom beam source. Surf Coat Tech. 2005;200(5-6):1645-51.

3. Wang S, Cai W, Li J, Wei W, Hu J. A novel rapid D.C. plasma nitriding at low gas pressure for 304 austenitic stainless steel. Mater Lett. 2013;105:47-9. http://dx.doi.org/10.1016/j. matlet.2013.04.031.

4. Naeem M, Shafiq M, Zaka-ul-Islam M, Nawaz N, Díaz-Guillén JC, Zakaullah M. Effect of cathodic cage size on plasma nitriding of AISI 304 steel. Mater Lett. 2016;181:78-81.

5. Vehovar L, Tandler M. Stainless steel containers for the storage of low and medium level radioactive waste. Nucl Eng Des. 2001;206(1):21-33. 
6. Li Y, Zhang S, He Y, Zhang L, Wang L. Characteristics of the nitrided layer formed on AISI 304 austenitic stainless steel by high temperature nitriding assisted hollow cathode discharge. Mater Des. 2014;64:527-34. http://dx.doi.org/10.1016/j. matdes.2014.08.023.

7. Abedi HR, Salehi M, Yazdkhasti M, Hemmasian-EA. Effect of high temperature post-oxidizing on tribological and corrosion behavior of plasma nitrided AISI 316 austenitic stainless steel. Vacuum. 2010;85(3):443-7. http://dx.doi.org/10.1016/j. vacuum.2010.08.008.

8. Naeem M, Shafiq M, Zaka-ul-Islam M, Díaz-Guillén JC, Lopez-Badillo CM, Ullah N, et al. Improved surface properties of AISI-304 by novel duplex cathodic cage plasma nitriding. Mater Lett. 2017;189:213-6.

9. Napiorkowski J, Szczyglak P, Ligier K, Kuczynski R. Testing the wear intensity of thin coatings by the ball-cratering method in the process of selecting punching die materials. J Balk Tribol Assoc. 2016;22(1):346-52.

10. Rousseau AF, Partridge JG, Mayes ELH, Toton JT, Kracica M, McCulloch DG, et al. Microstructural and tribological characterisation of a nitriding/TiAlN PVD coating duplex treatment applied to M2 high speed steel tools. Surf Coatings Technol [Internet]. 2015;272:403-8. http://dx.doi.org/10.1016/j. surfcoat.2015.03.034.

11. Sousa RRM, Sato PS, Viana BC, Alves C, Nishimoto A, Pedro A, et al. Cathodic cage plasma deposition of $\mathrm{TiN}$ and $\mathrm{TiO} 2$ thin films on silicon substrates. Journal of Vacuum Science \& Technology. 2015;041502.

12. Zhao C, Li CX, Dong H, Bell T. Study on the active screen plasma nitriding and its nitriding mechanism. Surf Coat Tech. 2006;201(6):2320-5.

13. Araújo FO, Sousa RRM, Costa JAP, Alves C Jr. Deposição de filme metálico em amostras de vidro em gaiola catódica. Rev Bras Apl Vácuo. 2008;27:149-52.

14. Daudt N F, Barbosa JCP, Braz DC, Pereira MB, Alves C Jr. TiN thin film deposition by cathodic cage discharge: effect of cage configuration and active species. J Phys Conf Ser. 2012;406:1-7.

15. Sousa RRM, Araújo FO, Costa JAP, Nishimoto A, Viana BC, Alves C. Deposition of TiO2 film on duplex stainless steel substrate using the cathodic cage plasma technique. Mater Res. 2016;19(5):1207-12.

16. Libório MS, Praxedes GB, Lima LLF, Nascimento IG, Sousa RRM, Naeem M, et al. Surface modification of M2 steel by combination of cathodic cage plasma deposition and magnetron sputtered $\mathrm{MoS}_{2}$-TiN multilayer coatings. Surf Coatings Technol. 2020;384:125327. https://doi.org/10.1016/j.surfcoat.2019.125327.

17. Kovács D, Dobránszky J, Fodor T, Takáts V, Bonyár A. Investigation of the ASPN process of low alloy steel by using $\mathrm{Ni}$ or $\mathrm{Cr}$ coated active screens. Surf Coatings Technol. 2020;394:125638. http:// dx.doi.org/10.1016/j.surfcoat.2020.125638.

18. Toshioka N, Nishimoto A. Surface-modified layer formed by plasma nitriding using chromium screen. Mater Trans. 2020;61:1115-21.

19. Karimoto T, Nishimoto A. Plasma-nitriding properties of cocrfemnni high-entropy alloys produced by spark plasma sintering. Metals (Basel). 2020;10(6):1-12.

20. Eduardo L, Santos H, Pizzatto A, Felipe M, Rabelo A. Effect of laser power and substrate on the hastelloy $\mathrm{C} 276^{\mathrm{TM}}$ oatings features deposited by laser cladding. Mat. Res. 2020;23(2):e20200067.

21. Villares Metals. Catálogo aço inoxidável austenítico - V304LUF [Internet]. 2003 [cited 2020 June 21]. Available from: http:// www.villaresmetals.com.br/pt/Produtos/Acos-Inoxidaveis/ Austeniticos/V304UF

22. Villares Metals. Catálogo aços para trabalho a frio - VC131 [Internet]. 2009 [cited 2020 June 21]. Available from: http:// www.villaresmetals.com.br/content/download/28447/288001/ file/VC131-pt.pdf
23. Rietveld HM. Line profiles of neutron powder-diffraction peaks for structure refinement. Acta Crystallogr. 1967;22:151-2.

24. Panjan M. Influence of substrate rotation and target arrangement on the periodicity and uniformity of layered coatings. Surf Coat Tech. 2013;235:32-44.

25. Li Y, He Y, Wang W, Mao J, Zhang L, Zhu Y, et al. Plasma nitriding of AISI 304 stainless steel in cathodic and floating electric potential: influence on morphology, chemical characteristics and tribological behavior. J Mater Eng Perform. 2018;27(3):948-60. http://dx.doi.org/10.1007/s11665-018-3199-8.

26. Corujeira Gallo S, Dong H. On the fundamental mechanisms of active screen plasma nitriding. Vacuum. 2009;84(2):321-5. http://dx.doi.org/10.1016/j.vacuum.2009.07.002.

27. Bashir MI, Shafiq M, Naeem M, Zaka-ul-Islam M, Díaz-Guillén JC, Lopez-Badillo CM, et al. Enhanced surface properties of aluminum by PVD-TiN coating combined with cathodic cage plasma nitriding. Surf Coat Tech. 2017;327:59-65.

28. Teles VC, Mello JDB, Silva WM. Abrasive wear of multilayered/ gradient CrAlSiN PVD coatings: effect of interface roughness and of superficial flaws. Wear. 2017;376-377:1691-701. http:// dx.doi.org/10.1016/j.wear.2017.01.116.

29. Both GB, Rocha AS, Santos GR, Hirsch TK. An investigation on the suitability of different surface treatments applied to a DIN X100CrMoV8-1-1 for cold forming applications. Surf Coatings Technol [Internet]. 2014;244:142-50. http://dx.doi. org/10.1016/j.surfcoat.2014.01.060.

30. Jurci P, Suchánek J, Hudáková M, Panjan P, Rízeková L. Characterization and performance of duplex-coatings on $\mathrm{Cr}-\mathrm{V}$ cold work tool steel. Mater Enfineering. 2015;22(1):126-39.

31. Ribeiro KJB, Sousa RRM, Araújo FO, Brito RA, Barbosa JCP, Alves C. Industrial application of AISI 4340 steels treated in cathodic cage plasma nitriding technique. Mater Sci Eng A. 2008;479(1-2):142-7.

32. Aharonov RR, Chhowalla M, Dhar S, Fontana RP. Factors affecting growth defect formation in cathodic arc evaporated coatings. Surf Coat Tech. 1996;82(3):334-43.

33. Lewis DB, Creasey SJ, Wüstefeld C, Ehiasarian AP, Hovsepian $\mathrm{PE}$. The role of the growth defects on the corrosion resistance of $\mathrm{CrN} / \mathrm{NbN}$ superlattice coatings deposited at low temperatures. Thin Solid Films. 2006;503(1-2):143-8.

34. Cunha LACG. Estudo dos mecanismos de degradação em revestimentos PVD baseados em nitretos metálicos no processamento de materiais plásticos [tese]. Braga: Universidade do Minho; 2000 [cited 2020 June 21]. Available from: https://repositorium. sdum.uminho.pt/bitstream/1822/177/1/tese_LCunha_Fisica.pdf

35. Liu K, Lei Y, Wang G. Correlation between oxygen adsorption energy and electronic structure of transition metal macrocyclic complexes. J Chem Phys. 2013;139(20):204306.

36. Parascandola S, Möller W, Williamson DL. The nitrogen transport in austenitic stainless steel at moderate temperatures. Appl Phys Lett. 2000;76(16):2194-6.

37. Serra PLC, Sousa RRM, Barros JR No, Libório MS, Feitor MC, Costa THC. Application of nitriding and duplex treatment on steel drills-HSS. J Multidiscip Eng Sci Technol. 2020;7(4):11699708.

38. Abreu LHP, Pimentel MCL, Borges WFA, Costa THC, Naeem $\mathrm{M}$, Iqbal J, et al. Plasma nitriding of AISI M2 steel: performance evaluation in forming tools. Surf Eng. 2020;36(5):508-15.

39. Sousa RRM, Moura YJL, Sousa PAO, Medeiros JQM No, Costa THC, Alves Jr C. Nitriding of AISI 1020 steel: comparison between conventional nitriding and nitriding with cathodic cage. Mater Res. 2014;17(3):708-13.

40. Nii H, Nishimoto A. Surface modification of ferritic stainless steel by active screen plasma nitriding. J Phys. 2012;379:1-7.

41. Sousa GS, Nobre FX, Araújo EA Jr, Sambrano JR, Albuquerque AR, Bindá RS, et al. Hydrothermal synthesis, structural characterization and photocatalytic properties of $\beta-\mathrm{Ag} 2 \mathrm{MoO} 4$ 
microcrystals: correlation between experimental and theoretical data. Arab J Chem. 2020;13(1):2806-25.

42. Balles AC, Schereiner WH, da Silva JM, Fontana LC. nitretação a plasma como meio alternativo ou complementar à oxidação negra na proteção à corrosão do aço de baixo teor de carbono. Rev Matéria. 2004;9:360-9.

43. Li XY. Low temperature plasma nitriding of 316 stainless steel-nature of $\mathrm{S}$ phase and its thermal stability. Surf Eng. 2001;17:147-52.

44. Jack KH. The iron-nitrogen system: the preparation and the crystal structures of nitrogen-austenite $(\gamma)$ and nitrogen-martensite ( $\left.\alpha^{\prime}\right)$. Proc. Math. Phys. Eng. Sci. 1951;208(1093):200-15.

45. Yousuf M, Sahu PC, Jajoo HK, Rajagopalan S, Govinda Rajan K. Effect of magnetic transition on the lattice expansion of nickel. J Phys F Met Phys. 1986;16:373-80.

46. Swanson HE, Gilfrich NT, Ugrinic G. Standard X-ray diffraction powder patterns. Natl Bur Stand Circ. 1955;539:1-75.

47. Nasr Eddine M, Sayetat F, Bertaut E, Paris J. Contribution a l'etude de $\mathrm{Cr} \mathrm{N}$ a basses temperatures par diffraction de rayons $\mathrm{X}$ et de neutrons. Comptes Rendus des Seances l'Academie des Sci Ser B Sci Phys. 1969;269:574-7.

48. Nascimento FC, Ferreira ELD, Foerster CE, Alves C Jr, Kuromoto NK, Paredes RSC, et al. Modificações estruturais induzidas por hidrogenação catódica em aço austenítico soldado e nitretado a plasma. Rem Rev Esc Minas. 2010;63(1):129-35.

49. Evans DA, Jack KH. The gamma -> beta phase transformation in the Mo-N system. Acta Crystallogr. 1957;10:833-4.

50. Hamilton WC. Neutron diffraction investigation of the $119 \mathrm{~K}$ transition in magnetite. Phys Rev. 1958;110:1050-7.

51. Alves C Jr. Nitretação a plasma: fundamentos e aplicações. Natal: EDFRN; 2001. 109 p.
52. Serra PLC, Furtado ASA, Barros JR No, Sousa RRM, Sampaio WRV, Costa THC. A review of duplex treatment effect on high- speed steel tools. J Multidiscip Eng Sci Technol. 2020;7(4):11738-49.

53. Golzar Shahri M, Hosseini SR, Salehi M, Naderi M. Evaluation of nitrogen diffusion in thermo-mechanically nanostructured and plasma nitrided stainless steel. Surf Coatings Technol. 2016;296:40-5. http://dx.doi.org/10.1016/j.surfcoat.2016.03.058.

54. Brandes EA, Brook GB. Smithells metals reference book. USA: Elsevier; 2013.

55. Hendricks SB, Kosting PR. The crystal structure of Fe2 P, Fe2 N, Fe3 N and Fe B. Zeitschrift fuer Krist. 1930;74:511-33.

56. Wakelin RJ, Yates EL. A study of the order-disorder transformation in iron-nickel alloys in the region Fe Ni3. Phys Met Metallogr. 1953;66:221-40.

57. Pereira JO No, Silva RO, Silva EH, Moreto JA, Bandeira RM, Manfrinato MD, et al. Wear and corrosion study of plasma nitriding F53 super duplex stainless steel. Mater Res. 2016;19:1241-52.

58. Gontijo LC, Machado R, Casteletti LC, Kuri SE, Nascente PA P. Comparação entre os comportamentos dos aços inoxidáveis AISI 304L e AISI 316L nitretados a plasma. Rev Bras Apl Vácuo. 2007;26:145-50.

59. Lima JA, Alves C Jr, Santos CA. Estudo do gradiente térmico no processo de nitretação a plasma thermal gradient study in the plasma nitriding process. Rev Matéria. 2005;10:273-83.

60. Daure JL, Voisey KT, Shipway PH, Stewart DA. The effect of coating architecture and defects on the corrosion behaviour of a PVD multilayer Inconel $625 / \mathrm{Cr}$ coating. Surf Coatings Technol. 2017;324:403-12. http://dx.doi.org/10.1016/j. surfcoat.2017.06.009. 